\title{
Against Simplicity: The Cultural Dimensions of the Constitution
}

\author{
J. David Greenstone $\dagger$
}

The Constitution of our country, instead of a democracy most simple, is the most complicated government on the face of the globe. ${ }^{1}$

John Quincy Adams

"Economics," writes Albert Hirschman, "has been grounded in a remarkably parsimonious postulate: that of the self-interested, isolated individual."2 Much as Hirschman attacks the economists' parsimony, this paper critiques the overly simplistic premises of two accounts of the American constitutional order. The American polity is notoriously complex: it embodies a federal system with autonomous legislative, executive, and judicial branches at every level. Yet the charter on which it rests is often construed in remarkably simple terms. The prevailing doctrinal view in the schools treats it as the ultimately authoritative text for adjudicating legal disputes. A contemporary radical critique sees it as a weapon wielded by one economic interest or another. For all the issues that divide these two accounts, each sees the existing constitutional order as exhibiting a single dominant pattern, which in each case is defined by one relatively cohesive set of interests and commitments. For one account, the regime's fundamental premises require a basically impartial polity and judicial system; for the other, they regularly sanction outcomes that have a pronounced class or other social bias. Against these views, I shall maintain that a constitution can truly shape a community's politics only if it expresses that community's culture-that is, its most fundamental ideas and practices. As I shall argue here, American political culture is indeed thoroughly liberal, but it is profoundly complicated

$\dagger$ Professor of Political Science, The University of Chicago. I should like to thank Chris Ansell, Isaac Balbus, Vickie Bertramson, Gerald Rosenberg, and the editors of this Review for their helpful comments on this paper.

1 John Quincy Adams, The Jubilee of the Constitution 115 (1839).

2 Albert O. Hirschman, Rival Views of Market Society and Other Recent Essays 142 (1986). 
nevertheless.

Accounts that take culture as their model differ sharply from the doctrinal and radical perspectives. As Clifford Geertz ${ }^{3}$ has so memorably asserted, cultural systems are sets of tools-basic beliefs, cognitive categories, affective attitudes and prescriptions for action. By providing the framework within which even unexpected experiences are rendered meaningful, such systems help the members of a political community react purposefully to those major and often unexpected changes that all societies eventually encounter. The emphasis here is not on the consistency of a set of beliefs, but on their cognitive use, on how they help or hinder the members of a community to cope with their experiences. If a belief is held because of its cognitive use, then its agreement or disagreement with other beliefs cannot be the decisive evaluative criterion. Indeed, if beliefs survive because they make important ranges of experience intelligible for those who hold them, then any contradictions or tensions among them are likely to be left unresolved. Accordingly, accounts based on cultural models cannot make any presumption, one way or the other, about the coherence of a polity's or society's belief system. Since some of these beliefs may appeal to one group, and other beliefs to another, this cultural perspective is quite likely to discern complexity rather than simplicity.

The thesis advanced here is cultural in this sense-and triply complex. First, it construes American constitutional politics in terms of three very different sets of informal as well as formal rules. Each set of rules plays a dominant role in a distinctive, but clearly liberal approach to the American regime. Second, this cultural thesis argues that two of these liberal approaches offer sharply opposed visions of the individual personality, social life, and the human condition itself. Third, this basic conflict within American liberalism is juxtaposed with a more consensual feature: a widely shared though narrowly political approach that emphasizes individual rights and republican institutions.

I would like to clarify two points at the outset. First, this discussion is by no means comprehensive. For example, the political importance of both black America and American Catholicism would require specific treatment beyond the scope of this paper. Second, the Constitution obviously plays a central role in both the American legal system and the political struggle for material ad-

s Clifford Geertz, The Interpretation of Cultures, especially chapters 4 and 8 (1973). 
vantage, often over the issue of economic inequality. My claim, therefore, is not that either the doctrinal and radical accounts are entirely wrong, but rather that each rests on a seriously flawed, because ultimately consensual, view of American culture.

\section{The Constitution and Political Interests}

\section{A. Authoritative Text or Political Weapon?}

For many American lawyers and legal scholars, the Constitution authoritatively shapes and limits legal and political processes. According to the doctrinal view, the Constitution and the agencies which implement it are devoted to the dispassionate adjudication of essentially neutral principles. According to Herbert Wechsler, "the main constituent of the judicial process is precisely that it must be genuinely principled, resting with respect to every step that is involved in reaching judgment on analysis and reasons quite transcending the immediate result that is achieved." $\mathrm{Or}$, as Wechsler later says, the courts "are bound to function otherwise than as a naked power organ." This view is succintly summarized by Robert Bork's aphorism, "the Constitution is law."" At least implicitly, then, the Constitution expresses and implements a consensual political logic that precludes conflict over fundamental issues within the American legal system.

To its radical critics, however, the claim that the Constitution is or can be a neutral, impartial framework is simply a mystification. In their view, the document is an instrument for achieving partisan objectives, typically those of the socially and economically privileged. Every polity must be based on some set of normative commitments, and the American regime is much more devoted to rewarding good fortune, hard work, and talent, than to securing equality of condition. Charles Beard offered the most celebrated statement of this position in An Economic Interpretation of the Constitution of the United States. ${ }^{7}$ But the Anti-Federalists made the same point when they said of the Constitution that "It changes, totally changes, the form of your present government. From a well-digested, well-formed democratic, you at once are

4 Herbert Wechsler, Toward Neutral Principles of Constitutional Law, 73 Harv.L.Rev. 1,15 (1959).

- Id. at 19.

- Robert H. Bork, The Constitution, Original Intent, and Economic Rights, 23 San Diego L.Rev. 823, 824 (1986).

7 Charles A. Beard, An Economic Interpretation of the Constitution of the United States (1929). 
rushing into an aristocratic government."8 It is this dismay with the existing order that leads contemporary scholars like Roberto Unger to seek what he calls an "empowered democracy" desiring, as Cass Sunstein observes in a critical essay, "to facilitate individual and collective self-transformation."

Each thesis clearly appears to contradict the other. To the radical critics, the doctrinal account simply ignores the Constitutions's social biases. Procedures that are neutral on their face may promote great inequalities in practice, and in the United States, the effect of liberal politics reinforces the effect of liberal economics. In a free market, each of my dollars is worth as much as each of yours, yet it makes all the difference if one of us has many more dollars than the other. So too, if some enter the political arena with more resources than others, formally impartial rules are likely to help the advantaged group acquire political power, which it can then use to preserve or increase social and economic inequalities. The general point here is that authoritative texts like the Constitution cannot be unambiguous and therefore self-implementing. Interpretation is always required. The more specific point is that every such interpretation must reflect social realities that include conflict between the advantaged and the underprivileged.

But the radical critics ignore the fact which the doctrinal adherents take as crucial: that the United States really does have a constitutional regime. Because the American Constitution is genuinely operative, it imposes a range of real constraints on political actors that free markets do not impose on buyers and sellers. Where some countries have constitutions in name only, for example, because they legitimate authoritarian regimes, constitutional rules in the United States are regularly regarded as final and determinative. Even if the line between church and state may change in some respects, the establishment of religion, in the eighteenth century sense, let alone a theocracy, is not now a serious option. Nor is there serious debate about how many senators should represent each state.

As a text, in other words, the Constitution is not indefinitely deconstructable. ${ }^{10}$ As presently written, it is not open to any plau-

Herbert J. Storing, What the Anti-Federalists Were For 48 (1981), quoting Lincoln, in Jonathan Elliot, 4 The Debates of the State Conventions on the Adoption of the Federal Constitution 313 (2d ed. 1866).

- Cass R. Sunstein, Routine and Revolution, 81 Nw.U.L.Rev. 869, 869 (1987), referring to Roberto Unger, Politics: A Work in Constructive Social Theory (1987).

10 This view contrasts with that expressed in Jacques Derrida, On Grammatology 15764 (1976). 
sible interpretation that might be suggested. The point is not just that certain procedures must be observed, for example, that a valid law requires a majority vote in each house and presidential assent. Nor is it that laws overtly discriminating against racial minorities cannot now be enforced. The real point, as the political struggle attendant on U.S. v. Nixon ${ }^{11}$ made clear, is that the American constitutional practice exacts obedience from all comers. Richard Nixon bowed to a final order of the courts because his allies as well as his foes insisted on it.

\section{B. Areas of Agreement: Conflicting Interests and Cultural Consensus}

Each side's arguments in this debate have been stated very starkly to clarify the areas of disagreement. Yet beneath these differences there are several levels of agreement. For example, each approach emphasizes the role of political interests-whether it be the impartial adjudication among them or the dominance of single faction. To be sure, the two accounts differ over which interests, if any, the constitutional order specially favors. But disagreements of this sort can often be resolved by specifying the circumstances and conditions under which different patterns appear. Moreover, there are some points on which the two perspectives may actually converge. First, the Constitution specifies the rules of the game, fair or unfair, within which the clash among economic groups or particular litigants takes place. Second, the constitutional order has legitimated some modes of conflict while proscribing others such as the open resort to violence by private parties. Witness the decline of violence on both sides in contemporary labor relations as compared to a century ago. Third, certain substantive constitutional issues are no longer matters of active dispute. Consider the sanctity of private property, which cannot be taken absent reasonable compensation (settled at or soon after the Founding), and the national government's role in welfare state programs (settled during and soon after the New Deal). Finally, existing constitutional arrangements-for example, the costliness of litigating important issues in the courts (such as nuclear reactor licensing) or campaigning for elective office-may directly affect the outcome of group struggles.

At one level, these various claims are unexceptional. For example, every serious analysis of American politics identifies some matters that are openly contested and others that are no longer (or 
not yet) in dispute. But the important point is a tendency on both sides to treat political issues as conflicts of interest. Neither account, in other words, views the Constitution primarily as a cultural system that helps Americans understand and cope with intrinsically puzzling or ambiguous events.

At least as important, these claims about conflicts of interests in American politics actually rest on a specific but often implicit position on the consensual character of American politics and culture. Note, for example, that even the radical perspective need not assume continuing conflict on basic issues. Indeed, the stronger the domination of a privileged elite, the less room there is for meaningful struggle. In the end then, both accounts can be readily bolstered by the consensus perspective on American political culture. As advocates of this consensus thesis have long argued, clashes over cultural matters can be ignored because American political culture as a whole is so powerfully, uniformly, liberal. ${ }^{12}$ This interpretation by no means precludes the existence of great objective inequalities. Rather, its most important version points out that these inequalities have failed to produce politically significant class conflict. ${ }^{13}$ American politics is so thoroughly liberal, so committed to limited government and individual liberties, that it extrudes all non-liberal political movements. Every such collectivism-be it proletarian socialism on the left, authoritarian paternalism on the right, or a nationalism of birth or ethnicity in the center-has more or less readily succumbed to a pervasive, even suffocating, liberalism. As the doctrinal view might rephrase this claim, the Constitution is the liberal framework that all politically active groups accept. For the radical critics, a dominant liberal cultural has systematically, via the Constitution, excluded all significant alternatives to a liberal, capitalist society. In either case, political conflict is restricted in the economic sphere to the clash of specific interests. The key point, then, is that both the doctrinal and radical views implicitly adopt a consensual view of American political culture as a point of departure, however much they differ on the normative merit of that consensus.

Paradoxical as it may seem, it is the very strength of this con-

12 See Louis Hartz, The Liberal Tradition in America (1955); Alexis de Tocqueville, Democracy in America (1945); Richard Hofstadter, The American Political Tradition (1948); Daniel Boorstin, The Genius of American Politics (1953); and Sacvan Bercovitch, The American Jeremiad (1978).

1s J. David Greenstone, Political Culture and American Political Development, 1 Stud.in Am.Pol.Devel. 1 (1986). 
sensual political culture that obscures its relevance for political life. The paradox follows both from the existence of a fundamental consensus and from its thoroughly liberal character. The fact that this consensus exists means that there is no serious political challenge to American liberalism. Given an agreement on fundamentals, both the political community and the scholars who study it are free to focus on specific conflicts, while taking for granted those factors that so powerfully unite them. The fact that the consensus is specifically liberal accounts for the concern with the interests of individuals and by extension, particular groups. All species of liberalism hold that individuals must be independent enough to decide how to act for themselves, either alone or with their likeminded fellows. But politics requires cooperation. As a result, the citizens of a liberal polity must somehow concert their activities. They must reconcile liberal autonomy with political authority and cohesion. Liberal political theory is renowned for its attention to just this problem-be it Hobbes' Leviathan, Locke's governmentas-umpire, or the focus on collective action in contemporary rational choice theory. Absent a solution to this latter problem, purely self-regarding individuals or groups will often fail to secure desirable or even indispensable public or collective goods such as law and order, national security, economic prosperity, or a protected environment.

These matters, of course, also confront other regimes. But they are particularly pressing for liberals who reject traditional, authoritarian or theocratic principles. And the study of American politics has indeed been preoccupied with the ways in which interest groups organize their members, struggle with each other, and try to find areas of compromise and accommodation. ${ }^{14}$

Thus, in sum, while the radical and doctrinal views differ on obviously important issues, they explicitly agree on the central place of interests in the American constitutional order, and implicitly agree on the character of American political culture. Because these interests are rather narrowly defined, the two interpretations can agree on certain factual issues, for instance, how the struggle is conducted and even who wins and who loses. Additionally, each view illuminates important facets of American political and constitutional practice, yet each can be supplemented by the consensus thesis.

Independently, or even more in combination, these approaches

14 J. David Greenstone, Group Theories, 2 Handbk.of Pol.Sci. 243 (1975). 
are indisputably impressive. In some versions, namely the rational choice literature and the analysis of legal doctrine, they are often formidably analytical. In others, especially explorations of the American cultural consensus, they are often theoretically and philosophically sophisticated. Yet certain questions persist. How can the political life of any complex society be so neatly limited to conflicts between competing interests? How can any political system, even one resting on so powerful a consensus, set cultural issues aside, thus indefinitely avoiding those issues of intelligibility and meaning that cultural systems address? How can a genuinely operative constitution be nothing more than an authoritative legal text, or the tool of a particular social faction, or perhaps some combination of the two? In short, does American constitutional politics really constitute one single thrust?

My complaint, then, echoes John Adams's unease about his friend Thomas Jefferson, and by extension many of his other compatriots. However sophisticated the tools Americans have for describing their social and political world, they see that world itself too simplistically. For example, as I have argued elsewhere, ${ }^{15}$ the consensus account is both revealing and misleading. What it reveals is the pervasiveness of American liberalism, and thus its capacity to exclude non-liberal alternatives from the American political agenda. But by focusing on specific conflicts of interest, it obscures the possibility that a culture can be pervasively liberal without being consensually so. In fact, even though American political culture sustains a broad agreement on liberal tenets, it exhibits three liberal, but very different approaches to basic constitutional issues: a republican account, now linked to a belief in individual rights; a humanist liberal account; and a reformed liberal account. The relationship among these approaches is particularly complex partly because each emphasizes a different type of constitutional rule. ${ }^{16}$

\section{The Cultural Alternative: Constitutional Rules}

Against this view, advocates of the doctrinal and radical positions might both advance a rule-based objection: the American

15 Greenstone, 1 Stud.in Am.Pol.Devel. at 19 (cited in note 13).

16 For a pioneering discussion of a rather similar three-fold typology, see Daniel J. Elazar, Cities of the Prairie: The Metropolitan Frontier and American Politics 258-66 (1970); Daniel J. Elazar, Cities of the Prairie Revisited: The Closing of the Metropolitan Frontier 83-86 (1986). The term "reformed liberalism" is taken from Franklin I. Gamwell, Beyond Preference: Liberal Theories of Independent Associations 9 (1984). 
Constitution and the laws that it sustains are above all a set of established rules for civil and political life. For the doctrinal view, impartial justice can be rendered only because these rules are by and large obeyed. For the radical view, a particular social faction can maintain its dominant, and legitimate, position only because the rules favoring it are widely accepted. From either point of view, then, the idea that a constitutional order presently encompasses fundamentally opposed perspectives must be incoherent.

The last half of this paper makes clear that my reply is finally substantive: it insists on the sheer existence of the very different republican, humanist, and reformed strands in our culture and constitutional order. But that reply also invokes a connected conceptual point: such a rule-based objection itself rests on a much too simplistic understanding of what the concept "rule" means-and thus the place of rules in our constitutional polity.

As already noted, constitutions are not self-enforcing. To talk about operative constitutions is to talk about certain socially accepted and culturally significant rules-whether or not they are formally part of the written document. And in the American case, such rules not only limit political life, but also help pattern both its conflictual and consensual features. The discussion that follows will first indicate three types of constitutional rules: constitutive provisions, norms, and precepts, and then will identify the distinctive ways in which they are linked to the three very different sides of American liberal culture.

Constitutive provisions stipulate the basic features of a practice or game. ${ }^{17}$ In basketball, for example, they specify what counts as a score (how many points are awarded for different types of baskets), when and how the ball may be put in play, and the like. Such rules identify basic facts as much as they assert obligations. It is a fact, for example, that people who violate such constitutive rules just do not play basketball.

Similarly, constitutions specify the members of a body politic, identify key political institutions and assign them particular powers and responsibilities (for example, the two-thirds vote required to override a Presidential veto), and establish the rights and obligations of both citizens and public officials. In one sense, such provisions are clearly arbitrary. There is no intrinsic reason for requiring this two-thirds vote for overrides, or for counting an ordinary basket as two points instead of five in basketball. Such rules are

${ }^{17}$ Stanley Cavell, Must We Mean What We Say? 24-31 (1969). 
often treated as binding simply because they remove some issues from debate and uncertainty.

By thus establishing relationships between citizens and government and among citizens themselves, constitutions encourage realistic expectations. Accordingly, it is the constitutive provisions of a polity as much as of a sport that most fully resist deconstruction. Without settled meanings, these provisions could not establish the framework essential for a complex political life. For instance, it is this framework that helps resolve a central problem in democratic theory, Arrow's Impossibility Theorem, emphasized by the rational choice literature: as the number of issues and alternatives to be considered increase, fully democratic solutions become difficult if not impossible. ${ }^{18}$ In practice, then, the relevant actors in a democratic regime must construe the key texts in the same way. However many interpretations might be conceivable or plausible, they must agree on what a polity's constitutive provisions mean.

Where constitutive provisions define a practice by specifying key actors, institutions and procedures, precepts advise those actors about their most effective courses of action. In basketball, they identify the best ways to shoot, pass, and play defense. In democratic politics, precepts informally shape the constitutional order. The character of both the American legislature and executive has changed profoundly as each branch has adopted and followed a growing body of precepts about using the mass media in appealing to the public and using technical experts on such matters as the budgetary process. In all such cases, the prevailing formula must be open to revision as new ideas and developments offer a better prospect for success. Where constitutive provisions resist deconstruction, precepts invite reformulation.

While constitutive provisions specify rather fixed procedures, and precepts are open to constant revision, norms or ethical ideals typically exhibit elements of both permanence and change. On one side, norms express the Constitutions's enduring cultural and philosophical commitments. Authoritatively asserted by public officials, enshrined in a polity's basic charter, and rooted in practices of long standing, this type of rule is likely to be quite permanent. In the American case, first amendment liberties as well as the equalitarian thrust of the Civil War and the women's suffrage amendments offer obvious examples. On the other side, since ideals and commitments are often not fully realized, these norms

1s Alfred F. MacKay, Arrow's Impossibility Theorem: The Paradox of Social Choice (1980). 
identify projects that a regime continues to pursue. Indeed, when they are wholly accepted, and come to define existing practices, they become constitutive provisions. In the case of race relations, for example, the right of minorities to vote now counts as such a provision, although it took over a century to become fully established. But the larger goal of racial equality remains a project yet to be realized. Here, disputes over interpretation-the meaning of "equality" is a notorious example-may readily reemerge.

\section{Three Accounts of the American Constitutional Order}

Taken by themselves, these differences among constitutional rules offer a provisional case against simplicity. A charter that embodies norms and precepts as well as constitutive provisions is not likely, it would seem, to function smoothly on behalf of some single goal or project. This supposition is correct, as least in the American case, in part because each of these types of constitutional rules figures prominently in a particular interpretation of the American constitutional order. And it is the difference in these interpretations that shows the inadequacy of any consensual approach, be it doctrinal or radical, to the American polity. Since space permits only a schematic discussion of each account, my object here will be to sketch their basic logic.

In the republican case, the emphasis is on constitutive provisions. Thus, political events are interpreted in terms of an opposition between the good of citizen virtue and the evil of usurpatious public officials. In the humanist liberal case, the emphasis is on precepts that facilitate effective action. Thus, relevant events are interpreted in terms of the tension between the value of autonomous individuals pursuing privately determined goals and the need for effective cooperation in pursuit of broadly shared objectives. Finally, reformed liberalism emphasizes the importance of constitutional norms. As we shall see, ethical issues in the American polity are interpreted in terms of a tension between holding individuals to appropriate moral standards and an obligation to see that every person can develop his or her faculties.

\section{A. Republicanism}

The most influential recent development in American political and intellectual history has been the study of republicanism. According to its advocates, English republican thinkers such as Harrington and Bolingbroke profoundly shaped the formative colonial period in American political development. Since this tradition can 
be traced back at least to Machiavelli, Polybius and the Roman republicans, and even Aristotle, its precise content remains in some dispute. Still, a number of persisting themes can be identified: an independent, virtuous, participatory citizenry, chastened and uplifted by honest labor; virtue understood as devotion to the general good of the community; the beneficent effect of landed property in contrast to artificial paper or financial wealth; honest legislators threatened by a corrupt executive's patronage and other blandishments; the danger of standing armies and more generally, all political power; and the remedies of short terms in office and a system of institutional checks and balances. ${ }^{10}$

The themes of virtue and the common good obviously echo important strains in ancient political thought. But for all the constraints it imposed on both citizens and officials, the founders' republicanism remained a liberal creed. First, it did not prescribe a comprehensive vision of human well-being, nor did it assign that function to any official body or collectivity, be it church, tribe, or polis. ${ }^{20}$ It valued republican polities because they imposed severe limits on the power of the state and its officials, leaving broader questions of individual and social good to the citizens themselves. Colonial republicanism was so much a theory of limited government that both Thomas Jefferson and John Adams linked it to a Lockean belief in individual rights with no sense of contradiction. Second, republican public spiritedness helped solve the characteristically liberal problem of coordinating autonomous, even warring individuals. Such coordination often depends on mutual reliance and widely trusted political institutions. By proscribing selfish behavior among either ruled or rulers and strictly limiting the government's power, republicanism offered just this prospect.

As David Ericson persuasively argues, republicanism was in fact one member of a family of liberal beliefs, all devoted to the ideal of individual liberation. ${ }^{21}$ But the jeremiads of seventeenth

10 See J.G.A. Pocock, The Machiavellian Moment: Florentine Political Thought and the Atlantic Republican Tradition (1975); Lance Banning, The Jeffersonian Persuasion: Evolution of a Party Ideology (1978); Bernard Bailyn, Ideological Origins of the American Revolution (1967); Gordon S. Wood, The Creation of the American Republic, 1776-1787 (1969); John P. Diggins, The Lost Soul of American Politics: Virtue, Self-Interest, and the Foundations of Liberalism (1984); Joyce O. Appleby, Capitalism and a New Social Order: the Republican Vision of the 1790's (1984).

${ }^{20}$ See Jean Yarborough, Republicanism Reconsidered: Some Thoughts on the Foundation and Preservation of the American Republic, 41 Rev.Pol. 61, 73 (1979).

${ }_{21}$ David Ericson, American Republicanism: 1787-1833: The Federal Farmer and Daniel Webster 30-47 (1987) (unpublished Ph.D. dissertation on file at the University of Chicago Department of Political Science). 
century New England suggest the extent to which many of the American colonists found the new ideal threatening as well as exhilarating. The elaborate constraints of seventeenth, eighteenth, and even nineteenth century republicanism reflected this genuine ambivalence. Such constraints were the reaction of committed liberals to the ever more individualist society and polity that they themselves were building. ${ }^{22}$ But if republicanism curbed the excesses of a new order, it was, to echo Madison, a liberal vaccine against a liberal disease. ${ }^{23}$

But how warmly have Americans actually embraced these republican values? What role did this doctrine play in the founding period and later? Although these questions remain a matter of scholarly debate, ${ }^{24}$ the literature clearly suggests an overall trend. While dominant in the early eighteenth century, republican thought was partially replaced about 1750 by a more Lockean concern with the social contract and natural rights. ${ }^{25}$ This decline continued after the founding, especially as utilitarian and populist ideas gained ground during the nineteenth century. A number of factors seemed to be at work. For one thing, the idea of the liberated individual became less threatening as it became more widely accepted, making an elaborate set of constraints seem less essential. For another, as lower and middle class reform movements gathered momentum in the nineteenth century, they took over much of the attack on self-interested politics. Here too, a specifically republican idiom seemed less necessary.

Yet this decline has been quite gradual. Though Adams and Jefferson gave a Lockean cast to the first half of the Declaration of Independence, they themselves continued to regard republican theorists as authorities. And they filled the second half of the Declaration with a litany of republican complaints. In the next decade, the Constitution itself guaranteed a republican form of government in Article IV. Later, during the antebellum period, both the Jacksonians and Whigs plausibly affirmed their attachment to some features of the republican outlook..$^{26}$ Even today republican

${ }^{22}$ See generally Marvin Meyers, The Jacksonian Persuasion (1954); Fred Somkin, Unquiet Eagle: Memory and Desire in the Idea of American Freedom, 1815-1860 (1967).

${ }^{23}$ Federalist 10, in Clinton Rossiter, ed., The Federalist Papers 77, 84 (1961).

${ }^{24}$ See Diggins, Lost Soul of American Politics (cited in note 19); Pocock, The Machiavellian Moment (cited in note 19).

${ }^{25}$ See Isaac Kramnick, Republican Revisionism Revisited, 87 Amer.Hist.Rev. 629, 637 (1982).

${ }^{26}$ See Meyers, Jacksonian Persuasion (cited in note 22); Daniel Walker Howe, The Political Culture of the American Whigs (1979); Ericson, American Republicanism (cited in 
precepts and norms remain part of American political culture. Prudential precepts continue to urge citizen vigilance against government usurpation and to prevent official misconduct.

More importantly, republican norms continue to reject any political analogue to market relationships in which individuals always seek their personal advantage. Rather than tolerating privately determined preferences or moral standards, they urge good citizens to sacrifice their own interests in order to preserve a liberal regime. And they wholly condemn the extremes of personal or familial influence in politics, and of selfishness and greed, that marked regimes such as the Marcos dictatorship in the Philippines and the many twentieth century oligarchies in Latin America. Of course, republican virtue is far from an achieved reality in the United States. However warmly Americans oppose official corruption, their governments, at all levels, often seem awash with it. But the fact that these sentiments are so often ignored only underlines their character as norms, as unfulfilled ideals.

In the long run, though, the most important republican legacy is procedural, achieved through the constitutive provisions that ensure a separation of powers. As crucial as an independent judiciary has been, the most significant consequence of the separation of powers may be the legislative independence secured by a system of fixed and different terms for the President, Senators, and Representatives-and especially, the quintessentially republican bar against executive officials serving in the Congress. Kept apart by these arrangements, Congress and the President are permanently at odds to a degree infeasible in parliamentary regimes. In fact, Congress regularly attacks the executive by invoking the republican shibboleth of perfidy and usurpation. Furthermore, this independence encourages deliberation and conscientious independence by the individual legislator, rather than the subservience to cabinet and colleagues that the eighteenth century republicans detested. Because many, though not all of these rules are essentially procedural, no single ideological or partisan cause always benefits. Indeed, over time, the same institution has been looked to for protection by very different social groups. Nevertheless, these arrangements are politically and culturally important. ${ }^{27}$

note 21).

27 I am grateful to Harry Hirsch, Arthur Maas, David Mayhew, Benjamin Page, and Richard Pious for making these points among others at a panel ("Roundtable on the Constitution and Contemporary Politics") on the continuing political importance of the Constitution at the 1987 annual meeting of the American Political Science Association, Chicago, 
American republicanism has come to focus on the essentially political relations between individuals and their government, and within the government itself. Even in colonial times, it did not clearly delineate a vision of the fully developed personality or the place of the individual in the good society. In this century, there are only traces of the earlier republican sociology, such as the celebration of yeoman farming as the guarantee of an independent citizenry. What offends contemporary republicanism is less the private ambition to get ahead than the impact this ambition may have on public life. To employ a distinction recently advanced by John Rawls, republicanism, together with a traditional American concern for individual rights, is now a specifically political rather than comprehensive or broadly social theory. ${ }^{28}$ In so far as it is a cultural tool that helps Americans interpret their experience, it does so by positing a basic opposition between the virtues of limited government and the usurpatious politicians' quest for power.

Yet by narrowing its scope in this way, republican doctrine may have retained its grip on the American mind. Almost all currents of American thought still accept the ideas of limited government, virtue and corruption, the separation of powers, and of course individuals rights. Here, indeed, is the real American liberal consensus. What remain in dispute are just those broader social and philosophical questions-the nature of the human personality and a good society-that are addressed by what Rawls calls comprehensive theories. ${ }^{29}$ And it is on just these matters that humanist and reformed liberals so sharply differ.

\section{B. Humanist Liberalism}

For humanist liberals, there is no higher appeal than the welfare of each human being, as she or he defines it. For that reason, equitably satisfying individual desires and preferences is the mark of a good society. Humanist liberals therefore value negative liberty, the freedom of individuals to determine their goals and to consider how best to achieve those goals with a minimum of external constraint. Where feasible, therefore, the polity and society should have the freedom promised by a capitalist economy. Indeed, the government's procedures and institutions have value if they provide the political equivalent of the impersonal market. But

Illinois.

${ }^{28}$ John Rawls, The Priority of Right and Ideas of the Good (unpublished paper delivered at the University of Chicago, Nov. 5, 1987).

28 Id. 
because politics is not economics, satisfying a complex set of preferences requires governmental action. It is this tension between the preferences of autonomous individuals and the need for government intervention that creates a concern with constitutional rules.

Some of these rules are norms, because complex sets of human objectives are rarely if ever fully satisfied. Since preferences often diverge, the government must do its best to reconcile competing demands and resolve private disputes in order that some individuals do not unduly infringe on the freedom of others. Individual disputants are more likely to be satisfied and to treat the authorities' decisions as binding when those decisions appear to be fair. Certainly, mutual trust depends in part on the perceived predictability and impartiality of the political environment.

At the same time, since preferences often converge, the government is also obliged to resolve the collective action problem. In the case of market failure, some expensive collective goods cannot be supplied to anyone unless they are supplied to essentially everyone. Here, private exchanges among rational, self-regarding individuals are insufficient, and this norm requires the government to use specific positive incentives and its powers of coercion to induce cooperation. But constitutive provisions are also vital because equitably providing goods of this type requires appropriate institutions and procedures. In particular, individuals are more likely to cooperate voluntarily and to accept the government's intervention in private life if its institutions are well designed.

In the end though, whether the issue is competition or cooperation, humanist liberals begin with individual preferences. Accordingly, their primary concern is instrumental and thus with precepts. For it is precepts that guide political actors in choosing the strategies and tactics, the politics and organizational forms, to be adopted in trying to satisfy their own or others' goals. Over time, such precepts have profoundly modified the American constitutional order. Executive agencies have learned to ensure security and support by forming "iron triangles," mutually beneficial alliances with interested pressure groups and congressional committees. At first, of course, this new pattern was highly politicized, for it sought to contest an existing distribution of power. But once it was institutionalized and diffused, it too acquired a quasi-constitutional standing, because it reshaped power relations throughout the political system. As Richard Pious points out, presidents and their advisers have treated a number of constitutional provisions, notably messages to the Congress and the power of the Com- 
mander-in-Chief, as resources for pursuing their goals. ${ }^{30}$

Recently, Jeffrey Tulis has shown that twentieth century practice created a new political pattern in which Presidents appeal directly to the people for support on critical policy questions. ${ }^{31}$ In effect, this precept has amended the initial constitutional arrangement in which presidential views on substantive policy issues were primarily addressed to Congress. Part of this change reflects new precepts, adopted by all sides, about using mass media to alter the competition established in 1787 between the White House and Capitol Hill. On the other hand, the resort to a congressional bureaucracy, including the Congressional Budget Office, has strengthened the legislature's capacity to resist presidential dominance.

In one sense, this concern with instrumental precepts is common to many different societies and cultures. Rather than being a specific way of interpreting problematic experiences, it emphasizes effective maneuvering in rather well-defined situations. To that extent, the cultural dimension of humanist liberalism may appear to be rather "thin." But this conclusion is somewhat misleading. As we have seen, the devotion to implementing individual preferences rests on a particular view of the human personality, the good society, and constitutional rules. And the division between the reformed and humanist sides of American liberalism does indeed have less to do with class or group interests than with sharply opposed cultural and philosophic commitments.

\section{Reformed Liberalism}

The opposition between humanist and reformed liberalism reflects a deep ambiguity in liberal thought: What is the scope of individual autonomy? On what issues are human beings the best judges of their own well being? Are individuals equipped to determine the basic goals they ought to pursue or simply to determine the means with which to pursue those goals? For humanist liberalism, individuals must choose the goals as well as the means, provided the freedom of others is respected.

Reformed liberals reject the humanist alternative because they answer these questions with a broadly Kantian ethic. They affirm a set of goals and duties whose origins can be traced back to the New England Puritan tradition. ${ }^{32}$ Individuals have an obligation (not

so Richard Pious, remarks delivered at the 1987 annual meeting of the American Political Science Association.

31 Jeffrey K. Tulis, The Rhetorical Presidency (1987).

${ }^{32}$ See J. David Greenstone, The Transient and the Permanent in American Politics, in 
just the option) to cultivate and develop their physical, intellectual, esthetic and moral faculties. These capabilities range from competence in language and ordinary mathematics, to a command of practical and moral knowledge vital for daily living, as well as to the arts and sciences sustained by cultural institutions, colleges, and universities. Taken together, they are the distinctive activities and achievements of the human species. Practiced by individuals, they make them full human beings and fully participating members of particular cultures and communities. Here, there can be no doubt about the ultimate end: to achieve mastery or excellence in activities of importance to one's community.

But is such an outlook genuinely liberal? Several considerations might seem to suggest a negative answer. Obviously, the opportunities to master various cultural forms are not equally distributed. Members of the upper classes, and especially their children, often use their cultural accomplishments to perpetuate their advantaged position. Just as clearly, any culture has limitations and blind spots that restrict the world view of some, or all, members of a society. Finally, any appeal to the ideas of mastery and competence may seem to be deeply coercive, when it seeks to control those whose moral and social development seems wanting. If Protestant moral reform fostered anti-slavery in the antebellum era, the same impulse supported Prohibition a generation later. Other forms of Protestant moralism, from blue laws to nativism, were prominent before the Civil War, and there may be echoes of this today among some fundamentalists.

These moralistic groups, to be sure, are clearly liberal. Most not only affirm republican values and institutions, but stress the importance of individuals taking responsibility for their actions. Still, their stand highlights a distinctive feature of the reformed outlook-even where it emphasizes the development of human faculties. Where the humanist polarity opposes competition and cooperation and the republican tradition pits civic virtue against the drive for political power, the reformed liberal opposition involves socially accepted standards. On the conformitarian side, the emphasis is on behavior-on obedience to moral norms. On the developmental side, the stress is on opportunity-on helping individuals develop their faculties for themselves according to the criteria for competence and excellence that are set by the individual's commu- 
nity or culture, or by the human condition itself. ${ }^{33}$ Accordingly, both sides of this opposition affirm a distinctive, and crucial tenet of reformed liberalism: the most vital ends of human activity are not properly matters of individual preference. Thus the question recurs whether any version of the reformed position-even the developmental one-can be fully and genuinely liberal. Three separate arguments support an affirmative answer.

First, like other liberal theories, the reformed version focuses on individuals. Where the humanist liberal focus is on individual preferences, the stress here is on individual faculties. Of course, not every political or ethical theory that emphasizes these faculties is a liberal theory. But the reformed position is liberal because of its view that development is an individual enterprise.

Second, since the project in question is self-development, the skills in question must be acquired by the person themselves (and not simply given to them). Accordingly, each individual, and not some religious, social or political authority, has the responsibility, as well as the right and opportunity, to determine just how this project should be undertaken. Each person must decide which abilities, activities, occupations, sports, or hobbies to choose, and then reap the reward for performing well, be it the success or the intrinsic satisfaction that such competence or excellence bring. In these respects, then, the individuals involved always remain sovereign with respect to means, however much the end reflects a widely accepted social or cultural understanding.

Yet these two arguments may seem to avoid the central issue: even those reformed liberals who stress liberation and development rather than conformity deny that all human goals are equally valid. Some occupations and some activities are less worthy than others because they do not substantially encourage the development of distinctively human abilities. But there is an answer to this objection: the real animus of liberal theory is against illicit forms of interpersonal domination. In the words of the liberal republican theorist Algernon Sydney, "Liberty solely consists in an independency upon the will of another." ${ }^{34}$ The real question, then, is whether the standards important to reformed liberals-for example, mastering the mother tongue of a monolinguistic culture-are imposed by some people on others. The short answer is

s3 See Greenstone, The Transient and the Permanent in American Politics (cited in note 32 ).

${ }^{34}$ Algernon, Sydney, Discourses Concerning Government 12 (3d ed. 1751), quoted in Banning, The Jeffersonian Persuasion at $47 \mathrm{n.18}$ (cited in note 19). 
that if a culture is to be coherent enough to survive, some of its central features must be beyond dispute. There must be some points on which significant disagreement rarely, if ever, arises, however vigorous the debate over the best means to achieve them. And Rousseau's Discourses aside, critics who attack existing cultures typically call for the development of proletarian cultural life, or some other alternative to the existing order. Their assaults on particular cultural forms rarely become an attack on the importance of acquiring cultural competence in general.

To use a somewhat different idiom, Locke's classically liberal notion of tacit consent has a cultural as well as a political dimension. It applies to a culture's basic practices and the norms that govern and evaluate performances within those practices. They are accepted almost universally, not as a matter of deliberate choice, but simply because (and to the extent that) the individuals concerned participate in that culture. Here, then, there is no question of some individuals subjugating others. As Wittgenstein suggests in a related connection, the issue is not whether particular individuals are free to accept this or that opinion as propounded by another. The point, instead, it how difficult or infeasible it is to reject a whole form of life, and the norms that pattern it, which a particular individual has already embraced. ${ }^{35}$

The fact that the reformed alternative is genuinely liberal illuminates certain cultural sources of American constitutional politics. Consider first the Constitution's constitutive provisions. The Civil War and the women's suffrage amendments in particular were products of the anti-slavery and feminist movements that espoused reformed liberal values. In their view, distinctions of race and gender were merely physical, and therefore not constitutionally acceptable, at least in part because blacks and women were human beings with distinctively human capacities. Since these amendments have become constitutive provisions, they help to identify the legitimate participants in the polity and, by extension, social life. In more problematic situations, reformed liberals adopt the precepts spawned by instrumental reasoning. Witness their extensive use of the courts for a variety of environmental and equal rights issues. ${ }^{36}$

But a devotion to helping every individual develop his or her faculties is essentially normative. Because they may not, and per-

23 Ludwig Wittgenstein, Philosophical Investigations II 241 (1958).

so Michael W. McCann, Taking Reform Seriously: Perspectives on Public Interest Liberalism 63 (1986). 
haps cannot, be fully realized, such norms are standards against which to measure a society's achievements. One such norm is education. Today, there is no serious constitutional objection to the federal government's support for either primary and secondary education, or its massive help to colleges and universities. Nor is there a serious challenge to the authority of the federal government-let alone states and localities-to support a quest for cultural excellence through agencies like the National Endowments for the Arts and the Humanities. However much the particular policies of the Endowments may be debated, their existence is largely taken for granted.

A somewhat similar account holds for the National Science Foundation. Here, to be sure, widespread support undoubtedly reflects the practical importance of the physical sciences and their apparently unproblematic criteria for making evaluative judgments. But the recent resistance to allowing creation science, and indeed the flat earth theory, in the public schools may signal more than a devotion to the separation between church and state. As the proponents of such theories rightly maintain, governmental policy is not neutral and impartial. But that policy's commitment is to. the scientific quest for truth-without regard to the preferences or even conscientiously affirmed religious beliefs that the members of the political community may have. Here, in other words, is an example of reformed liberalism's devotion to human excellence that requires at least an implicit stand, by the polity, on what counts as good science and what does not.

Reformed liberalism, then, has distinctively shaped the American constitutional order because it appeals to a far-reaching idea of a common life and culture. It goes beyond the republican approach, because its concern is widely social and cultural and not primarily political. It directly contradicts the humanist liberal interpretation of the Constitution, because its vision of a good society is not neutral with respect to preferences or desires, but ranks them in terms of intrinsic worth.

Some Americans, of course, may believe in both satisfying preferences and developing faculties. But the fact that they have internalized this opposition does not in itself eliminate the conflict. Certainly, the conflict has mattered politically in the past. It played a signal role in northern debates over slavery before the Civil War and in the civil rights protests in this century. Today, reformed liberalism finds any society wanting that fails to accord these opportunities to its citizens, whatever their or their parents' wealth or other social resources. It thus supports a critique of 
bourgeois society that is internal to the liberal enterprise, for its criticisms stem from liberal rather than radical premises. At times, that critique may emphasize the impact of poverty or homelessness on the opportunity for self development. But at other points, notably the recent struggle over Justice Powell's replacement, the issue may be an essentially cultural conflict over what the Constitution means. Two important inferences follow: first, that the doctrinal and radical accounts overlook this basic division within the American constitutional order; second, that conflict between the humanist and reformed sides of American liberalism is fundamentally cultural in character.

\section{ConCLusion}

If the conflict between humanist and reformed liberals is complex, so too is the American constitutional order. According to a familiar distinction between classical and modern ideas of the polity, the culture of the ancient polis was, or ought to have been, monolithic. And because there was no fundamental gap between politics and society, that culture found direct expression in its constitution. In terms of this distinction, then, modern thought treats political life as doubly complex. First, politics has become a clearly distinct arena with its own set of rules, institutions and actors. Second, politics typically exhibits deep cultural divisions on class, religious, or ethnic grounds.

In the American case, however, these conclusions are themselves too simple. On the one side, the American constitutional order and the culture into which it is woven exhibit consensus as well as basic disagreement. Republican values, individual rights, and the separation of powers are widely accepted, even though the humanist and reformed sides of American liberalism are divided on fundamental philosophical and cultural issues. On the other side, there is no sharp separation between politics and society. The point is not just that both American society and politics are thoroughly liberal. On certain issues, Americans may be deeply divided over what their Constitution means. But their disagreements involve complex matters of culture and social practice fully as much as legal doctrine or political and economic conflict. 